\title{
SELECTIVE REPRESENTATIONS AND THE ARCHAEOLOGY OF THE OTHER DEAD
}

\author{
Richard Bradley \\ University of Reading \\ Department of Archaeology \\ Whiteknights Box 227, Reading, RG6 6AB, United Kingdom \\ r.j.bradley@reading.ac.uk
}

The article presents a thoughtful and wide-ranging review of some important issues. My commentary will focus on just two problems that arise out of current research. The first is the relationship between the dead whose remains we excavate, and the artefacts that were sometimes deposited with them. The other question concerns those people whose bodies left little trace behind. These approaches feature different kinds of "selective representation". In the first example a partial image is created by the study of grave goods. In the second, the evidence offered by archaeological science can be equally incomplete. More serious is the contrast between the formal burials that occur in some contexts, and their virtual absence in others.

\section{SUBJECTS AND OBJECTS}

Traditional approaches to the dead have treated bodies in graves on the same terms as the artefacts that accompanied them, but such a direct connection was limited to the mortuary ritual. Although the dead person could have planned the funeral in advance, that guidance need not have been heeded and the choice of offerings to accompany the corpse 
was made entirely by the mourners. They had to decide how these objects were to be displayed and which aspects of the dead person's identity would be highlighted at the ceremony (Brück 2004). This can shed some light on ideas about the deceased, but the image was carefully contrived. At the same time human remains provide more direct information about the life history of the dead person. This might include evidence of biological sex, age, kinship, diet, health, upbringing, mobility and descent. These are the province of archaeological science. Thus any mortuary assemblage provides two independent sources of information - it tells how the deceased was portrayed by the mourners, and offers indications of his or her actual biography. They can result in strikingly different accounts, and it is a challenge to unite them.

A good example of the diversity of information is the grave of the "Amesbury Archer" who was buried only $4 \mathrm{~km}$ from Stonehenge (Fitzpatrick 20II). The people who conducted his funeral between about 2440 and $2290 \mathrm{BC}$ used distinctive artefacts to portray him in several different guises - as a hunter, a warrior, a metalworker, as someone who worked flint, and possibly as a leather worker too. His skeleton offers yet another narrative. He was an immigrant from the Continent and he was an invalid. It is hard to integrate such disparate material, especially since the number of objects found in his grave is altogether unprecedented. He has been claimed as a smith who visited Britain prospecting for copper, but there were no sources of this material anywhere in Wessex. He has been identified as a pilgrim attracted by the international reputation of Stonehenge as a ceremonial centre and a place for healing the sick (Darvill 20I6). The media have even claimed him as the person who organized the construction of the monument, but he was buried a significant distance away, on the far side of a major river, and in fact his funeral took place some time after the principal setting of monoliths was erected (Darvill et al. 20I3). The truth is that these anecdotal explanations are neither helped nor hindered by the findings of archaeological science. To my mind that is disturbing.

\section{THE OTHER DEAD}

As the author makes clear, her article concerns burial archaeology as well as the archaeology of death. At the risk of stating the obvious, they are not the same. All the people whose lives we investigate died a long time ago and very few of them were buried. The importance of the dead extends to those whose bodies left no trace. It would be wrong to limit the discussion to the comparatively rare instances in which human remains survive. 
If the Amesbury Archer was buried with enough equipment for several individuals, the remains of others are comparatively rare. His grave was located in an area where many burials have been found, but on any reckoning too few people are represented to have built all the monuments there. It would still be true if they had drawn on assistance from other communities. Even in a region with an unusual density of burial mounds most of the dead have disappeared. One might respond that archaeologists can study only the bodies that survive, but surely an "archaeology of death" must start by asking why some people were not commemorated. In any kind of social archaeology that is as just important as the distinctions among the grave goods.

To come to terms with this question we have to contend with at least four issues. To keep this discussion within limits I shall draw on examples from pre-Roman Britain, although the same problems apply to the archaeology of the European mainland. Detailed accounts of the available information are provided by Bradley (2007) and Darvill (2010).

- Were there periods of the past in which human burials were absent or under-represented? And were there others in which they were more frequent?

This is a crucial source of variation and one that is seldom addressed. How can there be an "archaeological study of the dead" if their remains cannot be found? To give just one example, no Late Mesolithic cemetery has so far been discovered in Britain, but many of the stone and earthwork monuments dating from the early part of the Neolithic period contain the unburnt remains of men, women and children. It seems possible that other human bones circulated among the living. Entire bodies may originally have been deposited at these sites, but it is clear that after an interval selected parts were removed. That may be why they are also found at settlements and enclosures. In lowland Britain the frequency of human remains diminished after the middle of the fourth millennium $\mathrm{BC}$ and only a few cremation burials date from the next 500 years. They come from a small number of major monuments, especially Stonehenge where they have been studied in detail (Willis et al. 20I6). The situation changed again during the Bell Beaker phase when deposits of human remains were more common, usually as inhumation burials in flat graves or below small mounds. The frequency of human remains bears no relationship to other well-documented trends. The number of people represented at any one time is not related to the extent of settlement or the intensity of land use as measured by environmental archaeology. Nor can the frequency of human burials be linked with the amount of labour invested in building monuments. 
- Were graves left intact, or were their contents later inspected or removed? Did relics taken from older graves circulate among the living? Were the entire contents of cremation pyres collected after a funeral, or did burnt bones and fragmentary pyre goods pass between the survivors?

Again the British sequence raises issues that are seldom discussed. The inhumation graves of the Copper Age and the first part of the Early Bronze Age raise particular problems. They were frequently recut, so that any one of them may include several separate burials (Garwood 2007). More than that, it seems as if older burials were disturbed or even rearranged and that body parts (and presumably artefacts) might have been taken away. On one level, the remains of the dead could have been inspected, augmented or reorganized. On another, older graves may have been a source of relics used by the living together with portable artefacts. That has not always been appreciated. New work by Ann Woodward and John Hunter (2015) has shown that the objects assembled in burials had gone through long and varied histories and that that many of them can be identified as heirlooms. They may have been buried together, but it is clear that they were made at different times from one another and had distinctive biographies of their own. They had not been the exclusive possessions of the person buried. Indeed Woodward and Hunter identified cases in which artefacts classified as grave goods were made from human bone. Other isolated bones are known from settlements of the same date. By contrast, the burial mounds constructed towards the end of the Early Bronze Age include the remains of entire bodies inhumations and especially cremations - which remained undisturbed.

A further complication has been identified by Joanna Brück (2009) in a study of Bronze Age cremation burials in Britain. She observes that the weight of burnt bone recovered by even the most careful excavation is rarely enough to account for an entire corpse. That might have happened because fragments were never recovered from the pyre - perhaps a sample was considered sufficient. Alternatively, selected relics may have circulated among the living, as seems to have happened with unburnt bones during earlier periods. It is important to excavate pyre sites as thoroughly as cremation burials, but in Britain they have been hard to discover and were not always located in cemeteries.

- How many collections of human remains were buried without any grave goods, and were objects of the kinds that would normally accompany the dead deposited in other locations?

This is an even more difficult problem, as unaccompanied burials in Britain have seldom been investigated by radiocarbon dating. Graves 
were usually dated by studying the artefacts associated with them, and most samples were processed in order to measure the chronology of diagnostic objects - there was little concern with burial archaeology. Until comparatively recently unaccompanied deposits of burnt and unburnt bones were rarely studied and their frequency is unknown. In the case of Bronze Age Britain, it raises a more troubling issue. Where bodies were not associated with grave goods was this because they did not feature at the funeral, or were there cases in which gifts had been provided for the dead at the funeral but were separated from the body at the funeral ceremony? They might have been removed from the cremation pyre before a corpse was burnt, and appropriate offerings could have been deposited in a separate location. An obvious example is river metalwork, for finds of weapons occur in water from precisely the time when they vanish from the funerary record. It happened in many parts of Europe and this distinctive pattern was by no means confined to the Bronze Age. Unfortunately, it is not the only possible explanation for this relationship. Had cremations been deposited in running water together with metal items, no trace of them is likely to survive. Again it is impossible to estimate how many human remains have vanished, and yet this is an important question if we are to comprehend past attitudes to the dead.

- How often are human bones identified in places that were not primarily associated with the dead?

This is a problem that affects the archaeology of many parts of Europe where burnt and unburnt human bones are discovered away from cemeteries. Here they are often associated with settlements. They can occur in many different contexts - in houses, grain storage pits, waterholes, wells and middens, as well as field systems, enclosure ditches and land boundaries. Some fragments may have been taken there directly from a pyre, but others had never been burnt. Their frequency has been underestimated in the past and it is difficult to tell how commonly they occurred, but their wide distribution among the deposits in later prehistoric settlements raises the possibility that they represent the normal way of treating the dead. In that case the formal cemeteries of the later Bronze and Iron Ages - however distinctive their contents - were actually exceptional. This is another problem that needs investigation. A full account of the archaeology of death must allow for this problem.

Finally, a word about ethics. The article rightly considers the propriety of excavating and displaying human remains and emphasizes the importance of showing respect for the dead whose remains we study. Could this principle be taken further? Surely we should become more aware of 
those lives that left no visible trace behind. At best the methods of archaeology are ingenious - at worst they are tortuous and obscure - but they are the only ways of preserving any record of people who were lost to view once they died. They were the "other dead".

\section{REFERENCES}

Bradley, R. 2007. The Prehistory of Britain and Ireland. Cambridge: Cambridge University Press.

Brück, J. 2004. Material Metaphors: The Relational Construction of Identity in Early Bronze Age Burials in Ireland and Britain. Journal of Social Archaeology 4: 3307-33.

Brück, J. 2009. Women, Death and Social Change in the British Bronze Age. Norwegian Archaeological Review 42:I-23.

Darvill, T. 20Iо. Prehistoric Britain. Second edition. Abingdon: Routledge.

Darvill, T. 20I6. A Prehistoric Healing Centre and Pilgrimage Sites in Southern Britain. In: Ranft, A. \& Schenjuhn W. (Eds.). Kulturstraßen als Konzept: 20 Jahre Straße der Romanik. Pp. I55-66. Regensburg: Schell and Steiner.

Darvill, T., Marshall, P., Parker Pearson, M. \& Wainwright, G. 20I 2. Stonehenge Remodelled. Antiquity 86: IO2 I-40.

Fitzpatrick, A. 20II. The Amesbury Archer and the Boscombe Bowmen. Salisbury: Wessex Archaeology.

Garwood, P. 2007. Before The Hills in Order Stood: Chronology, Time and History in the Interpretation of Early Bronze Age Round Barrows. In: Last, J. (Ed.). Beyond the Grave. Pp. 30-52. Oxford: Oxbow.

Wills, C., Marshall, P., McKinley, J., Pitts, M., Pollard, J., Richards, C., Richards, J., Waldron, T., Welham, K. \& Parker Pearson, M. 2016. The Dead of Stonehenge. Antiquity 90: 337-56.

Woodward, A. \& Hunter, J. 2015. Ritual in Early Bronze Age Grave Goods. Oxford: Oxbow. 